\title{
Normatywny model opieki nad sierotami w XVI-wiecznych rewizjach prawa chelmińskiego. Zarys instytucji
}

Na mocy przywileju Kazimierza Jagiellończyka z 1476 r. prawo chełmińskie uznane zostało za wyłącznie obowiązujące na terenie całych Prus Królewskich, stając się tym samym powszechnym prawem prowincjonalnym. Istotnym problemem związanym z jego nowym statusem był jednak brak jednolitej kodyfikacji, mogącej stanowić rzetelną podstawę orzeczniczą oraz praktyczne źródło wiedzy. Dotychczasowe zbiory nie regulowały wielu podstawowych zagadnień, koniecznych do kompilacji o charakterze systemowym, wykazując jednocześnie szereg poważnych sprzeczności normatywnych, uniemożliwiających ich bezpośrednią recepcję. Stan ten miał zmienić powstały na początku XVI w. szlachecko-mieszczański ruch kodyfikacyjny. Wpisywał się on w szerszy nurt ukierunkowany na ujednolicenie i reformę w zakresie prawa powszechnego, stanowiąc odpowiednik działań podejmowanych w ustawodawstwie koronnym. Owocem prac połączonych komisji były trzy rewizje: lidzbarska $(1566)^{1}$, nowomiejska $(1580)^{2}$ oraz toruńska $(1594)^{3}$. Narastający konflikt między stanami, dotyczący zasadniczo kwestii spadkowych (sukcesja flamandzka) spowodował, że żaden z projektów nie zyskał akceptacji sejmu pruskiego i jako taki nie został uznany za zbiór obowiazzujący. Nadto niezadowolona $\mathrm{z}$ braku realizacji swych postulatów szlachta podjęła się uchwalenia własnej kodyfikacji w myśl zasad polskiego prawa ziemskiego. Normatywnym efektem działań stronnictwa szlacheckiego była Korektura Pruska z 1598 r., \footnotetext{
lej: RL].

- Rewizja nowomiejska prawa chetmińskiego 1580 (1814) zwana także ius culmense emendatum lub ius culmense polonicum, red. Z. Zdrójkowski, przekł. I. Malinowska-Kwiatkowska, J. Sondel, Toruń 1993 [dalej: RN]; J.W. Bandtkie, Jus culmense, cum appendice privilegiorum et jurium selectorum municipalium, et dissertatione historicojuridica, exhibitum, Warszawa 1814.

${ }^{3}$ Ius Culmense ex ultima revisione oder das vollständige Kulmische Recht, wyd. M.C. Hanow, Danzig 1767 [dalej: JC]
}

${ }^{1}$ Rewizja lidzbarska prawa chelmińskiego 1566 [1711], przekł. A. Groth, Koszalin 1997 [da- 
w zasadniczym stopniu odbiegająca od praktyki chełmińskiej ${ }^{4}$. Niezależnie od tego rewizje stały się obok przywileju z $1233 \mathrm{r}^{5}{ }^{5}$ oraz pomniejszych pomników ustawodawstwa partykularnego ${ }^{6}$ jednym $\mathrm{z}$ najważniejszych źródeł prawa chełmińskiego, co ugruntowało ich przyjęcie przez część ośrodków stosujących jego zasady?

Dużo uwagi rewizje chełmińskie poświęcają instytucji opieki nad sierotami (tutela impuberum). Ten recypowany z prawa rzymskiego rodzaj reprezentacji, w dotychczasowej literaturze poruszany najczęściej na marginesie innych problemów badawczych, miał zasadnicze znaczenie w wypadku śmierci jednego lub obojga rodziców dziecka ${ }^{8}$. Opiekun od momentu ustanowienia miał obowiązek czuwać nad osobistymi i majatkowymi sprawami pupila, reprezentując go $\mathrm{w}$ razie potrzeby $\mathrm{w}$ stosunkach $\mathrm{z}$ osobami trzecimi. Bez niego małoletni, jako pozbawiony zdolności do czynności prawnych, nie mógł przedsiębrać skutecznych prawnie działań, co powodowało upośledzenie jego pozycji względem pozostałych podmiotów prawa oraz z racji niemożności pozwania dziecka mogło ograniczać prawa innych (np. wierzycieli spadkowych). Stąd też przygotowując poszczególne projekty starano się uregulować przynajmniej najważniejsze zagadnienia tuteli, biorąc pod uwagę zarówno interes samego dziecka, jak i innych bezpośrednio zainteresowanych ustanowieniem opieki osób. Pod względem materialnoprawnym zbiory przyjęły jeden, niewykazujący znaczących różnic model reprezentacji. W podobny sposób unormowano powołanie opiekuna, jego odpowiedzialność, sposób wykonywania opieki oraz przesłanki jej wygaśnięcia. Różnice pomiędzy poszczególnymi kompilacjami mają charakter nieistotny i polegają na stylistycznych zmianach opracowywanego tekstu oraz, sporadycznie, na rozszerzeniu regulacji w celu większego dostosowania do wymogów praktyki. Model ten miał przy tym

${ }^{4}$ Volumina Legum, t. VI, Petersburg 1860, s. 270-282; Z. Zdrójkowski, Korektura pruskajej powstanie, dzieje oraz jej rola w historii polskiej jurysdykcji i myśli prawniczej (1598-1830), „Czasopismo Prawno-Historyczne” T. XIII, 1961, z. 2, s. 109-132.

K. Zielińska-Melkowska, Przywilej chetmiński 1233 i 125I, Torun 1986; J.C. Kretschmer, Die Kulmische Handfeste, Marienwerder 1832.

${ }^{6}$ T. Maciejewski, Partykularyzm prawna gdańskiego (XV-XIX w.), w: Partykularyzm a unifikacja prawa w Polsce (XV-XX w.), Gdańsk 1994, s. 34-38.

Z. Zdrójkowski, Zarys dziejów prawa chetmińskiego (1233-1862). Studium z okazji siedemsetpięćdziesięciolecia wydania przywileju chetmińskiego oraz lokacji miast Chetmna i Torunia, Toruń 1983, s. 31-49.

${ }^{8}$ J. Sondel J., Elementy romanistyczne w rewizjach prawa chelmińskiego: lidzbarskiej (Jus Culmense Correctum - 1566 r.), nowomiejskiej (Jus Culmense Emendatum-1580 r.) oraz toruńskiej (Jus Cumlense Revisum-1594 r.), w: Studia Culmensia historico-juridicia czyli Ksiega pamiatkowa 750-lecia prawa chetmińskiego, red. Z. Zdrójkowski, t. 2, Toruń 1988, s. 149-234. Klasyczny model opieki oraz jego recepcje do prawa niemieckiego omówili J.B. Wiesner, Das Vormundschaftsrecht, Halle 1785; A.A.F. Rudorff, Das Recht der Vormundschaft aus den gemeinen in Deutschland geltenden Rechten, Bd. 1, Berlin 1832.

${ }^{9}$ RN, s. 16-23 (tabela konkordancyjna: Rewizja Lidzbarska i Nowomiejska). W zbiorze z roku 1566 i z 1580 podobnie jak w Prawie Starochetmińskim przepisy dotyczące opieki umiejscowiono tuż za regulacją dziedziczenia testamentowego i ustawowego. W Rewizji Toruńskiej zrezygnowano 
charakter ogólny. Normatywizacji podlegały podstawowe instytucje związane ze sprawowaniem opieki, kwestie szczegółowe pozostawiono zaś ustawodawstwu partykularnemu oraz obowiązującym na danym terenie zwyczajom. Było to rozwiązanie zgodne $\mathrm{z}$ generalnym charakterem rewizji, względem których normy partykularne stanowiły swoiste lex specialis.

Nie bez znaczenia dla treści zbiorów jest fakt, że prawo chełmińskie stanowiło odmianę prawa magdeburskiego. Już w XIII-wiecznym przywileju lokacyjnym Torunia i Chełmna zastrzeżono, ,aby w tych miastach na wieki przestrzegane było prawo magdeburskie"10. W praktyce miało ono charakter subsydiarny, znajdując zastosowanie w przypadku, gdy dana materia nie była przedmiotem regulacji prawa chełmińskiego (przywileju i powstałego na jego podstawie prawa zwyczajowego) i zachodziła tym samym konieczność odwołania się do innej podstawy normatywnej. Rozwiązanie to zostało w późniejszym czasie przyjęte także przez inne miasta lokowane oparte na wzorcu chełmińskim, stając się jedną z głównych zasad systemu. Jej realizacji sprzyjało opracowanie poszczególnych zbiorów magdeburskich, ich publikacja drukiem, a przez to względna łatwość dostępu. Największe znaczenie miało przy tym Speculum Saxonum ${ }^{11}$ i Ius municipale Magdeburgen$s e^{12}$ autorstwa Mikołaja Jaskiera, którym Zygmunt I nadał w 1535 r. charakter urzędowy, uznając je za jedynie obowiązujące w miastach posługujacych się tym prawem ${ }^{13}$. W 1581 r. syndyk lwowski Paweł Szczerbic przetłumaczył Zwierciadlo Saskie na język polski, publikując je wraz z osobnym tłumaczeniem magdeburskiego prawa miejskiego (Weichbild ${ }^{14}$. Zbiory Jaskiera stały się ponadto przedmiotem licznych komentarzy. Do najważniejszych glosatorów należał mieszczanin krakowski Bartłomiej Groicki, który na podstawie Weichbild i Speculum Saxonum, dokonał wykładu podstawowych zasad sasko-magdeburskich, przedstawiając oraz komentując ich praktyczne zastosowanie w obrocie. Szczególną uwagę opiece nad sierotami Groicki poświęcił w książce Obrona sierot $i$ wdów, wydanej już po jego śmierci $(1605)^{15}$. Zawie-

z takiego ujęcia włączając je do księgi IV, poświęconej szeroko rozumianym zobowiązaniom kontraktowym. W księdze tej wyodrębniono osobny tytuł: „O opiekach” (Titulus Decimus Quartus: Von Vormundschaften).

${ }^{10}$ K. Zielińska-Melkowska, Przywilej chetmiński, s. 38 (art. 4).

${ }_{11}^{11}$ M. Jaskier, Juris provincialis quod Speculum Saxonum, Kraków 1535.

${ }_{12}$ M. Jaskier, Juris Municipalis Maideburgensis liber vulgo Weichbild, Kraków 1535.

${ }_{13}$ Tekst rozporządzenia królewskiego przytoczył S. Ehrenkreutz, O stosunkach majatkowych między malżonkami wedlug prawa chetmińskiego w Warszawie $w$ wieku XVI, ,Odbitka ze Sprawozdań z Posiedzeń Towarzystwa Naukowego Warszawskiego. Wydział Nauk Antropologicznych, Społecznych, Historyi i Filozofii. Posiedzenie z dnia 29 stycznia 1915 r.”, R. VIII, z. I, s. 5-6.

${ }_{14}$ P. Szczerbic, Speculum Saxonum albo prawo saskie y magdeburskie porzadkiem obiecadla, $z$ lacinskich y niemieckich exemplarzow zebrane, Lwów 1581; idem, Jus municipale, to jest prawo miejskie magdeburskie nowo z lacińskiego i z niemieckiego na polski język z pilnościq $i$ wiernie przelożone, Lwów 1581.

15 B. Groicki, Obrona sierot i wdów, Warszawa 1958. 
ra ona rozszerzony względem popularnych Tytułów prawa magdeburskiego ${ }^{16}$ model prawa opiekuńczego, wzorowany w większości na pracach prawnika flandryjskiego Jodoka Damhoudera ${ }^{17}$. Oprócz przepisów traktujących o sierotach, w Obronie omówiono także inne formy opieki: nad wdowami, chorymi psychicznie, marnotrawcami, niepełnosprawnymi. Całość zaś zamyka wyciag najważniejszych praw, statutów i konstytucji.

Istotne jest również to, że w trakcie prac nad Rewizją Lidzbarska, jako jedną $\mathrm{z}$ głównych podstaw normatywnych, wykorzystano rozpowszechnione na terenie państwa zakonnego Prawo Starochetmińskie (Der alte Kulm) ${ }^{18}$. Kompilacja ta, oparta na XIII-wiecznych pouczeniach Magdeburga dla Wrocławia, uzupełnionych odpowiednio ortylami wydanymi dla Chełmna i przepisami Zwierciadła Szwabskiego, stanowiła zwód zasad właściwego prawa magdeburskiego ${ }^{19}$. Uwidaczniały to w szczególności normy z zakresu sukcesji spadkowej, przede wszystkim odrzucenie charakterystycznej dla prawa chełmińskiego instytucji wspólności majątkowej małżonków (communio bonorum). Przewidywała ona, że wraz z zawarciem małżeństwa majątek obojga nupturientów tworzył jedna, niepodzielną na czas trwania związku całość. W razie śmierci któregoś z nich i braku odmiennych dyspozycji testamentu, spadek dzielony był na dwie, równe pod względem wartości części. Jedną dziedziczył żyjący współmałżonek (tzw. połowa chełmińska), drugą obejmowali pozostali uprawnieni do dziedziczenia krewni, według przysługujących im z mocy prawa udziałów ${ }^{20}$. W Prawie Starochelmińskim wspólność została całkowicie zastapiona przez główne zasady sasko-magdeburskie, w istocie ograniczające spadkobranie kobiet $^{21}$. W dalszej perspektywie projekt lidzbarski stał się podstawą kompilacji nowomiejskiej oraz ostatniego ze zbiorów chełmińskich - Rewizji Toruńskiej ${ }^{22}$.

Konsekwencja powyższego stanu było przejęcie $\mathrm{z}$ prawa niemieckiego podstawowych pojęć i konstrukcji prawnych, dostosowanych odpowiednio do praktyki orzeczniczej Prus. Już wstępne porównanie treści tuteli według prawa magdeburskiego $\mathrm{z}$ kompilacjami chełmińskimi wykazuje daleko idące podobieństwa między oboma systemami, oparte na wspólnym założeniu normatywnym. Różnice pojawiają się zasadniczo w kwestiach szczegółowych, na

${ }^{16}$ B. Groicki, Tytuły prawa maydeburskiego do porządku $i$ do artykulów, pierwey po polsku wydanych. W sprawach tego czasu naywieccey kłopotnych z tegoż prawa maydeburskiego przydatne, Kraków 1760, s. 175-183 (przedruk wydania z 1616).

${ }^{17}$ B. Groicki, Obrona, s. I-II (,Wstęp").

18 RL, s. 23-24. Prawo starochelmińskie 1584 (1394), red. W. Maisel, Z. Zdrójkowski, przekł. A. Bzdęga, A. Gaca, Torun 1985 [dalej cyt. PS]; Das alte Kulmische Recht (mit einem Wörterbuche), wyd. C.K. Leman, Berlin 1838.

${ }_{19}$ P. Laband, Das Magdeburg-Breslauer systematische Schöffenrecht aus der Mitte des 14. Jahrhunderts, Berlin 1863 (w szczególności: s. 168-170; cap. 58-64).

${ }^{20}$ RL, s. 181 (art. 23); RN, s. 93-94 (art. 52); JC, s. 141-142 (cap. XI).

${ }^{21}$ PS, s. 101-127 (Księga IV).

22 Z. Zdrójkowski, Zarys dziejów, s. 35. 
co miały niewatpliwie wpływ zarówno warunki lokalne, jak i specyfika oraz odrębności niektórych instytucji ius culmense. Wydaje się zatem słuszne, aby analizując wskazany problem przynajmniej w niezbędnym zakresie odwołać się do norm magdeburskich, mających w systemie chełmińskim podstawowe znaczenie.

Według Bartłomieja Groickiego opieką,nic innego nie jest jedno moc nad człowiekiem lat nie mającym, który zostawszy po śmierci ojcowskiej, sam siebie dla swojej młodości rządzić nie umie, dana od tego co czynił testament albo od urzędu"23. To ujęcie, tożsame dla większości nowożytnych systemów prawnych, zawierało zarówno generalne ratio legis instytucji opieki nad sierotami, jak i dwie zasadnicze podstawy powołania opiekuna. Potrzebę jego ustanowienia upatrywano przede wszystkim w wieku sieroty. Wiązała się z tym zdolność do samodzielnego zarządzania swoją osoba, mieniem, właściwej oceny podejmowanych działań i ich skutków. Małoletni jako nieposiadający odpowiedniej wiedzy oraz szeroko rozumianego doświadczenia życiowego był tego pozbawiony. W dotychczasowym układzie wszystkie ważniejsze decyzje podejmował rodzic i on też brał za nie odpowiedzialność. Jego śmierć stanowiła punkt kluczowy dla przyszłości potomka, który z jednej strony tracił osobę najbliższą, której obowiązkiem była piecza nad nim, z drugiej zaś stawał się spadkobiercą dziedzicząc jej dobra. Chodziło jednak nie tylko - jak pisał Groicki - o śmierć ojca, ale również o matkę, po której zgonie także należało zabezpieczyć interes sieroty. Podstawy ku temu dawały niezliczone spory majątkowe, w których żyjący rodzic, krewny czy osoba trzecia, bezprawnie zagarniała mienie dziecka wykorzystując brak odpowiedniej nad nim kontroli. Temu właśnie zapobiec miało powołanie opiekuna. Prawo chełmińskie przewidywało, że tutora można było ustanowić bądź to w drodze dyspozycji ojca (opieka ojcowska), a w wypadku braku takiego zapisu - przez urzędowe wyznaczenie spośród najczęściej najbliższych, mogących pełnić tę funkcję, krewnych (opieka urzędowa) ${ }^{24}$. W każdym razie, nawet w przypadku ustanowienia za życia rodzica, dopiero śmierć wstępnego powodowała powstanie obowiązku opieki nad dzieckiem i jej późniejsze objęcie. Fakt ten wyraźnie zaznacza Rewizja Nowomiejska, tłumacząc, że choć dozwolone jest wyznaczenie przyszłego opiekuna, to „,niewłaściwie nazywa się [to] opieka, dopóki ojciec pozostaje przy życiu"25. Przepis ten wyłączał tym samym możliwość swobodnego przekazywania kompetencji rodzicielskich, opierając się na przekonaniu, że do czasu śmierci rodzica wszelkie prawa i obowiązki związane z osobą i majątkiem małoletniego nie mogły być wykonywane w formie opieki.

${ }^{23}$ B. Groicki, Tytuty, s. 175

${ }^{24}$ Inaczej opieka nadana, przydana, ustawowa, tutela dativa (P. Dąbkowski, Prawo prywatne polskie, t. I, Lwów 1910, s. 496).

${ }^{25}$ RN, s. 99 (art. 66). 
Pierwszeństwo w systemie chełmińskiego prawa opiekuńczego miała dyspozycja ojca. Rewizje poświęcają jej stosunkowo niewiele miejsca, pozostawiajac właściwą regulację prawu zwyczajowemu i skupiają się na rodzącej więcej wątpliwości opiece $\mathrm{z}$ urzędu. Unormowano jedynie prawo rodzica do powołania tutora, nie wskazując przy tym jasno formy jego ustanowienia ani ewentualnych ograniczeń w tym zakresie ${ }^{26}$. Praktyka potwierdza, że podobnie jak w prawie magdeburskim rodzic wskazywał opiekuna w akcie ostatniej woli. Testament, będący najważniejszym przejawem intencji spadkodawcy, w którym - cytując Ignacego Czerwińskiego - „człowiek staje się prawodawcą dla swych dzieci i swojej fortuny", pozwalał na swobodne wybranie osoby powołanej, z możliwością pominięcia osób obieranych z urzędu ${ }^{27}$. Testator zaznaczał w tym celu powołanie, podając jednocześnie dane przyszłego opiekuna (imię, nazwisko, pełnioną godność, stopień pokrewieństwa itd.) w sposób nie budzący wątpliwości w momencie otwarcia oraz późniejszego ogłoszenia testamentu. Zapis niejasny, nieprecyzyjny albo niezgodny z prawem mógł zostać podważony, a w efekcie unieważniony na zasadach właściwych dla czynności tego rodzaju ${ }^{28}$. Tak jak w przypadku innych dyspozycji post mortem, ojciec miał prawo w każdej chwili odwołać wcześniej wskazaną osobę albo powołać na jej miejsce inna. Musiał przy tym zachować prawnie przewidzianą formę zmiany (odwołania) testamentu. Ostatecznemu wykonaniu podlegała ostatnia, właściwe sporządzona, spełniająca kryterium skuteczności testowania (podmiotowe i przedmiotowe), dyspozycja spadkodawcy ${ }^{29}$.

Jeżeli rodzic nie ustanowił opieki lub zapis skutecznie podważono, zgodnie z przepisami rewizji tutora wyznaczała rada miasta bądź inna „zwierzchność danej miejscowości" ${ }^{30}$. Przez zwierzchność rozumiano organ, który na mocy ustawodawstwa wewnętrznego, właściwego dla danego miasta czy wsi był kompetentny do ustanowienia opiekuna. Kandydata na tę funkcję poszukiwano najpierw wśród najbliższych krewnych dziecka. W pierwszej kolejności powoływano najstarszego, zamieszkałego w okręgu sądu spadku krewnego w linii ojczystej. Po śmierci spadkodawcy w celu objęcia opieki zgłaszał się on do rady, która rozważając kandydaturę musiała wyrazić zgodę na jego ustanowienie oraz przyznać odpowiednią legitymację do prowadzenia spraw sieroty ${ }^{31}$. W razie uznanej w świetle prawa niemożności podjęcia bądź usprawiedliwionej odmowy przyjęcia obowiązku, wyznaczany był kolejny

${ }^{26}$ Zob. P. Dąbkowski, Prawo prywatne, s. 489-490.

${ }^{27}$ I. Czerwiński, Przewodnik testatora czyli ważne uwagi tyczqce się potrzebney wiadomości. o czym y iak testamenta pisać się powinny, 1803, s. 11 (Biblioteka Zakładu Narodowego im. Ossolińskich we Wrocławiu, Dział Rękopisów, sygn. 2839/I).

${ }^{28}$ T. Maciejewski, Dziedziczenie testamentowe w prawie miast pruskich, w: Prawo wczoraj i dziś. Studia dedykowane profesor Katarzynie Sójce-Zielińskiej, red. G. Bałtruszajtys, Warszawa 2000, s. 180-188.

${ }^{29}$ Ibidem.

${ }^{30}$ RL, s. 195 (art. 53).

31 JC, s. 189 (cap. I). 
najbliższy krewny małoletniego, zgodnie ze stopniem pokrewieństwa i miejscem zamieszkania. Jeżeli dziecko nie miało krewnych zdolnych do sprawowania pieczy, rada zobligowana była do powołania osoby niespokrewnionej, gwarantującej zdaniem urzędu właściwą reprezentację. W tym zakresie prawo chełmińskie dawało pełną swobodę w doborze określonego opiekuna, przy czym rada powinna się kierować przede wszystkim jak najlepszym interesem dziecka oraz jego mienia. Wybierając tutora starano się zatem, żeby była to osoba o stosunkowo wysokim statusie społecznym (co najmniej równym pupilowi), nieposzlakowanej opinii oraz powszechnie szanowana. Groicki radził nawet, aby dobierać na urząd „męże poważne, stateczne, opatrzone, uczone, w sprawowaniu rzeczy biegłe, ćwiczone, ile może być we wszystkim ku sprawowaniu opieki najgodniejsze, którzy by byli dobrzy, pobożni, sprawiedliwi, miłosierni, w rządzeniu i opatrowaniu sierot i dóbr ich sprawnemi"32. Jednocześnie prawo zezwalało na powołanie kilku opiekunów (współopieka). W takim wypadku każdy $\mathrm{z}$ nich był zarazem i uprawniony, i zobowiązany do prowadzenia opieki, co przekładało się na charakter odpowiedzialności poszczególnych tutorów. Konieczność powołania z urzędu mogła być także rezultatem śmierci osoby wyznaczonej przez ojca, niemożności lub odmowy przyjęcia przez nią opieki albo odwołania z pełnionej funkcji, gdy na przykład bezprawnie pomniejszała majattek sieroty. W tej sytuacji właściwy organ zmuszony był do wyznaczenia innego opiekuna, według zasad przewidzianych dla opieki urzędowej.

Ograniczony wpływ na wybór sprawującego opiekę miał też sam małoletni. Jeżeli chłopiec ukończył 14 lat (dziewczynka odpowiednio 12), mógł za zgodą krewnych i rady wskazać własnego kandydata do opieki ${ }^{33}$. Kandydatura tej osoby musiała jednak zostać zatwierdzona przez urząd, który miał prawo odmówić powołania. Po skończeniu 18 roku życia nieletni mógł nadto zażądać zmiany tutora, gdy ten nienależycie dbał o jego interesy majątkowe. Zmianę musiała ponownie zaakceptować rada lub inny organ, ,albowiem - jak podkreśla przepis rewizji - jeśli sam [pupil - P.K.] zechce ustanowić własnego opiekuna według własnego uznania, ani rada, ani urząd ziemski, ani bliscy niech nie tolerują jego zuchwalstwa"34. Poza tym, jeżeli dotychczasowy opiekun wykazał, że opieka była wykonywana prawidłowo i co za tym idzie zarzuty sieroty okazały się bezpodstawne, zachowywał prawo do dalszej reprezentacji.

Co do wymogów, które powinna spełniać dana osoba, by móc zostać powołana do opieki, rewizje wypowiadają się nader lakonicznie. Brakuje w tym względzie określenia okoliczności negatywnych, tak jak to miało miejsce na przykład w przypadku ustawodawstwa koronnego ${ }^{35}$. Można jednak wskazać

32 B. Groicki, Obrona, s. 27.

${ }^{33}$ RL, s. 233 (art. $55 \S 5$ ); RN, s. 98 (art. 65); JC, s. 141 (cap. IV).

${ }^{34}$ RN, s. 97-98 (art. 64).

35 P. Dąbkowski, Prawo prywatne, s. 498-500. 
przesłanki, które w razie zaistnienia wykluczały (ewentualnie mogły wykluczać) potencjalnego tutora od sprawowania pieczy, przez co uniemożliwiały powołanie na tę funkcję $\mathrm{z}$ mocy prawa. Podstawowym warunkiem było posiadanie pełnej, niczym nieograniczonej zdolności do czynności prawnych oraz zdolności procesowej. Wynikało to z możliwości składania skutecznych w świetle prawa oświadczeń woli, dokonywania ważnych czynności prawnych i w konsekwencji realizowaniem związanych z opieką podstawowych obowiązków. W myśl uregulowań ius culmense pełnej zdolności do czynności prawnych nie miały: osoby niepełnoletnie (poniżej 21 roku życia), chore psychicznie (poza okresami zdrowia w chorobie - lucida intervalla), marnotrawcy, banici, infamiści i kobiety. Ponadto wyłączano od powołania zarówno osoby wcześniej skazane za nadużywanie opieki, jak i orzeczonych krzywoprzysiężców ${ }^{36}$. Charakter popełnionych czynów jednoznacznie dyskwalifikował je w stosunku do jakiejkolwiek reprezentacji, w tym także do występowania w charakterze świadka. Obok tego istotnym wymogiem było zamieszkiwanie opiekuna w okręgu właściwego dla majątku sądu. Brak faktycznego domicylu mogło w ocenie kodyfikatorów negatywnie wpływać na możliwość rzeczywistego sprawowania opieki oraz należytego zarządu nad dobrami, tym bardziej że w praktyce mienie dziecka tworzyły często składniki wymagajace sporych nakładów czasu i pracy tutora ${ }^{37}$.

Objęcie tuteli miało na gruncie prawa chełmińskiego charakter obowiązku. Był on niezależny tak od podstawy powołania, jak też wyrażenia przez bezpośrednio zainteresowanego zgody na jej pełnienie. Każdy kto został ustanowiony opiekunem powinien się opieki podjać i sprawować ją w sposób zgodny $\mathrm{z}$ interesem dziecka. Rewizje przewidywały jednak katalog osób, które z ważnych powodów - zajmowanej funkcji, wykonywanego zawodu, wieku, stanu zdrowia i wcześniejszej, kilkukrotnej reprezentacji małoletnich - mogły uchylić się od powołania. Byli to: wykonujący funkcje publiczne, doradcy królewscy, żołnierze, dostojnicy, profesorowie medycyny, złożeni ciężką choroba, mający ukończony 70 rok życia oraz osoby powołane wcześniej trzykrotnie na funkcje tutora $z$ urzędu ${ }^{38}$, przy czym same nie starały się o opiekę $e^{39}$. Jednocześnie nie wykluczało to prawa organu ustanawiającego do uwzględnienia innej, aniżeli wymienione w katalogu przyczyny, uzasadniającej jego zdaniem odmowę jej objęcia. Okoliczności te powinny być brane pod uwagę również

36 RN, s. 97 (art. 64 zd. 3).

37 Por. JC, s. 190 (cap. II).

38 JC, s. 194-195 (cap. XII); RN, s. 100 (art. 71).

${ }^{39} \mathrm{~W}$ komentarzu Hanow thumaczy, że opiekę mogli również wymówić niespokrewnieni z dzieckiem kościelni oraz nauczyciele (JC, s. 195, przyp. 155). Według prawa magdeburskiego katalog ten obejmował nadto osoby pełnoletnie poniżej 25 roku życia, ubogich, posiadających liczne potomstwo, osoby mające „,Z rodzicami sieroty jakie zaszcie albo nieprzyjaźn” (B. Groicki, Tytuły, s. 176-177), będące „na służbie pana swego w dalekich krajach” (B. Groicki, Obrona, s. 25), niemych, ślepców oraz głuchych (P. Szczerbic, Speculum Saxonum, s. 296). 
przez testatorów, jako że opiekuni powoływani z testamentu także mieli prawo do odrzucenia pieczy, co mogło skutkować niezrealizowaniem woli spadkodawcy w tej części.

Jeżeli ustanowiony tutor celowo nie podejmował się opieki, istniała możliwość sądowego zmuszenia go do realizacji obowiązków. Wierzyciele zmarłego, którzy z racji braku faktycznie sprawowanej reprezentacji nie mogli dochodzić roszczeń względem majątku sieroty, mieli prawo pozwać najbliższego agnata i na drodze orzeczenia sądu zmusić go do prowadzenia spraw dziecka. Musieli oni jednak wykazać, że uchylanie się krewnego od opieki miało na celu ochronę dóbr pupila przed długami ${ }^{40}$. Jeżeli krewny przyznał się do bezprawnego zaniechania opieki, orzeczeniem sądu odpowiadał w imieniu dziecka o wskazany w pozwie dhug. Pozwany mógł jednak uwolnić się od zarzutów przez udzielenie przysięgi, w której zaświadczał, że uchylanie się od tuteli wynikało $\mathrm{z}$ innych uzasadnionych powodów. W tej sytuacji ius culmense zezwalało na wystapienie do rady o niezwłoczne ustanowienie innego opiekuna oraz publiczne zabezpieczenie praw wierzycieli na majatku sieroty. Skutkowało to sądowym zastawem dóbr, uniemożliwiającym swobodne rozporządzanie majątkiem aż do momentu ostatecznego rozliczenia $z$ wierzycielami. Jeżeli tutor skłamał i zostało mu to udowodnione, to oprócz odpowiedzialności za dług mógł zostać pociagnięty do odpowiedzialności karnej, jaką prawo chełmińskie wiązało z krzywoprzysięstwem.

Opieka nad nieletnimi w systemie chełmińskim rozumiana była jako surogat władzy ojcowskiej ${ }^{41}$. Wynikało stąd wiele uprawnień i obowiązków opiekuna oraz zaostrzona względem naturalnej opieki rodziców odpowiedzialność za prowadzenie spraw dziecka. Podstawowym obowiązkiem tutora było wspomniane czuwanie nad interesami majątkowymi i osobistymi pupila. Przystępując do opieki powinien on zapoznać się ze stanem majątku podopiecznego, dokładnie określić jego składniki oraz sporządzić urzędowy inwentarz wszystkich posiadanych przez dziecko dóbr (aktywa i pasywa). Egzemplarz repertorium przedkładał sądowi lub radzie, wskazując tym samym punkt wyjściowy tuteli, istotny w momencie okresowego oraz ostatecznego rozliczenia z opieki. Docelowo miało to zabezpieczyć majątek małoletniego przed bezpodstawnym uszczupleniem ze strony nieuczciwego dysponenta lub pogorszeniem w czasie wykonywania zarządu ${ }^{42}$. Służyło ono też ochronie interesów samego opiekuna. Niesporządzenie poprawnego inwentarza mogło stać się podstawą późniejszych, niekoniecznie zasadnych roszczeń podopiecznego i w konsekwencji jego odpowiedzialności majątkowej. Stąd też w prawie magdeburskim niewykonanie spisu bądź też nieusprawiedliwione zwlekanie $\mathrm{z}$ inwentaryzacja, jako budzące podejrzenie możliwego naruszenia, stanowiło

\footnotetext{
${ }^{40}$ RN, s. 99-100 (art. 70); JC, s. 190 (cap. III).

41 P. Dąbkowski, Prawo prywatne, s. 488.

42 JC, s. 191-192 (cap. VI).
} 
bezwzględną przesłankę odwołania tutora i zarazem pozbawienia go prawa do sprawowania opieki w przyszłości ${ }^{43}$. Karane było również umyślne sporządzenie rejestru niekompletnego. Jeźeli okazało się, że opiekun celowo zataił część majątku, podając do inwentarza jedynie wybrane jego elementy, groziło mu uznanie za krzywoprzysiężcę. W sytuacji gdy przemilczany przedmiot stanowiły przysługujące wierzycielom długi, tutor mógł nadto zostać zobowiązany do ich spłaty (do wysokości należnego świadczenia) ${ }^{44}$. Co do samej formy dokumentu, jak i warunków jego skuteczności rewizje mówią niewiele, poprzestając na ogólnym wskazaniu, że ma on obejmować całokształt sytuacji majątkowej pupila. Kwestie szczegółowe, jak choćby uczestnictwo urzędników, świadków czy jego weryfikacja, pozostawiono prawu partykularnemu, co zresztą właściwe było także dla prawa magdeburskiego.

W zakresie zarządu opiekuńczego należy wyróżnić dwie sytuacje: zarządu zwykłego i czynności przekraczające zwykłe zarządzanie mieniem. Opiekun mógł swobodnie podejmować decyzje związane jedynie ze zwykłym uźywaniem rzeczy, w granicach racjonalnie pojętego, bieżącego administrowania dobrami. Wszelkie czynności przekraczające zwykły zarząd, jak choćby alienacja nieruchomości (gruntów, budynków), obciążenie zastawem czy wydzierżawienie, wymagały wyraźnego zezwolenia władz nadzorujących jego działania ${ }^{45}$ i w razie konieczności mogły być przedmiotem stosownej skargi ze strony krewnych sieroty lub postępowania $z$ urzędu ${ }^{46}$. Dotyczyło to nie tylko majątku nieruchomego i ruchomego, ale również przysługujących małoletniemu roszczeń, które podobnie jak pozostałe składniki mienia nie mogły ulec bezprawnemu pomniejszeniu ${ }^{47}$. Obowiązkiem było w tym zakresie zabezpieczenie wierzytelności oraz ich prawidłowe ściąnięcie od dłużników. Z drugiej strony tutor kontrolował wszystkie czynności rozporządzające dziecka i musiał dla ich skuteczności wyrazić na nie zgodę. Miał on prawo sprzeciwić się każdemu rozporządzeniu, które uznał za niezgodne $\mathrm{z}$ interesem pupila, a ten zobowiązany był decyzji się podporządkować. Odzwierciedlenie tej zasady znajdujemy także w Speculum Saxonum, które stanowiło, że ,jeśliby co takiego sierota bez woley opiekunowey uczynił, to nic nieważy, gdyż sierota ani skargi kłaść, ani dziedzictwa przyjmować, ani o nie prawem czynić albo postępować, ani ich używać, ani obiecować, ani obietnic przyjmować nie może bez przyzwolenia opiekuna swego" 48 .

Ze swojego zarządu opiekun składał rachunki stanowiące podstawę kontroli jego bieżącej działalności oraz aktualnej sytuacji majątkowej sieroty ${ }^{49}$.

\footnotetext{
${ }^{43}$ B. Groicki, Obrona, s. 31-32.

44 Ibidem.

${ }^{45}$ RN, s. 99 (art. 68); JC, s. 192-193 (cap. VIII).

${ }^{46}$ RL, s. 176-177 (art. 13).

${ }^{47}$ RN, s. 101 (art. 75).

48 P. Szczerbic, Speculum Saxonum, s. 295-296.

${ }^{49}$ RN, s. 99 (art. 69).
} 
Organ pełnił w tym względzie funkcje „opiekuna zwierzchniego" (Obervormund), nadzorującego z urzędu sprawowaną opiekę, dysponującego środkami kontrolnymi z możliwością odwołania tutora włącznie ${ }^{50}$. Określał on przede wszystkim termin, w którym opiekun powinien dokonać okresowego rozliczenia, zwyczajowo nie rzadszy niż raz na rok. Obejmowało ono wszystkie dochody z zarządzanego majątku i poczynione w danym okresie wydatki. Raz do roku możliwa była również kontrola rodziny, przy czym uprawnionymi do żądania rachunków byli oprócz samego pupila jego matka oraz inni najbliżsi krewni $^{51}$. W razie watpliwości opiekun musiał uzasadnić określone czynności wyjaśniając podstawę ich dokonania. Jeżeli wykazano, że działanie było bezprawne, mógł on zostać pociągnięty do odpowiedzialności za szkodę wyrządzoną swoim działaniem lub zaniechaniem.

Odpowiedzialność majątkowa opiekuna miała charakter nieograniczony. Pupil, zgodnie z prawem zwyczajowym, na wszystkich jego dobrach, zarówno ruchomych, jak i nieruchomych, posiadał milczącą hipotekę, uprawniająca go do pierwszeństwa zaspokojenia przed innymi wierzycielami nierzetelnego krewnego $^{52}$. Karą za prowadzenie spraw w złej wierze oprócz odpowiedzialności materialnej była także infamia i całkowity zakaz pełnienia jakiejkolwiek reprezentacji w przyszłości. Uniemożliwiało to zarówno ponowne powołanie do opieki, jak i skutecznie ograniczało zdolność procesową skazanego. Opiekun mógł zbić skargę, jeżeli udowodnił, że szkoda nie była wynikiem jego winy, a nastapiła z przyczyn od niego niezależnych. Za takie rewizje uznają między innymi rabunek ${ }^{53}$. W razie wytoczenia powództwa o bezprawne uszczuplenie majątku mógł on także uwolnić się od odpowiedzialności udowadniając, że dobra te zostały spożytkowane na utrzymanie dziecka i związane $\mathrm{z}$ tym niezbędne wydatki ${ }^{54}$. Podstawe obrony stanowiły rachunki opieki oraz inne wskazane przez oskarżonego środki dowodowe. Z racji konsekwencji prawnospadkowych skazania, dowód ten można było przeprowadzić również po śmierci tutora, opierając się na zeznaniach trzech wiarygodnych oraz równych pupilowi stanem świadków. Było to o tyle ważne, że w razie śmierci pełniącego opiekę za wszelkie zobowiązania wynikłe w związku ze sprawowaną opieką odpowiadali jego spadkobiercy. Roszczenie to wchodziło wtedy w skład długów spadkowych, które jako takie powinny być spłacone aż do całkowitego zaspokojenia pupila ${ }^{55}$.

${ }^{50}$ JC, s. 192 (cap. VII).

${ }^{51}$ RL, s. 194 (art. 50); JC, s. 191 (cap. IV). W Prawie Starochelmińskim tutor powinien składać rachunki dwa razy do roku (PS, s. 126, art. 103)

${ }_{53}$ RN, s. 100 (art. 73); JC, s. 193 (cap. IX).

${ }^{53}$ RN, s. 97 (art. 63).

${ }_{55}^{54}$ RL, s. 234 (art. $55 \S 9$ ).

${ }^{55}$ RN, s. 98 (art. 64). W przypadku przyjęcia z dobrodziejstwem inwentarza spadkobiercy odpowiadali w granicach wartości aktywów spadku. 
Wykonując opiekę tutor musiał brać pod uwagę skutki nie tylko własnych działań czy zaniechań, ale również przedsięwzięcia podopiecznego. Zakres jego odpowiedzialności rozciagał się na wszelkie czynności rozporządzające małoletniego, które ostatecznie zatwierdził i w ten sposób uczynił skutecznymi prawnie. Jeżeli opiekun nieopatrznie zgodził się na dokonanie rozporządzenia, które w efekcie przyniosło nieuzasadnioną stratę w dobrach, mógł odpowiadać w granicach szkody ${ }^{56}$. Wyjściem $\mathrm{z}$ tej sytuacji mogło być skorzystanie z przysługującego sierocie roszczenia o przywrócenie do stanu poprzedniego. Pupil, który w drodze kupna, sprzedaży czy też innej czynności doznał szkody mógł, usprawiedliwiając się wiekiem i względami słuszności, żądać przywrócenia „utraconej korzystnej sytuacji”, a więc uchylenia niekorzystnego $\mathrm{z}$ jego punktu widzenia kontraktu czy wyroku sadowego i tym samym powrót do stanu sprzed dokonanej czynności lub wydanego orzeczenia ${ }^{57} . Z$ racji zatwierdzenia przez uprawnionego przedstawiciela było to jednak niezwykle trudne. Ryzykownym aspektem opieki była również realizacja prawa bliższości (retraktu). Retrakt stanowił uprawnienie najbliższych krewnych (obojga płci) do odkupienia od nabywcy rzeczy nieruchomej, sprzedanej przez któregoś z bliskich członków rodziny ${ }^{58}$. Termin na jego zrealizowanie wynosił zwyczajowo rok od momentu sprzedaży i musiał być poprzedzony sądowym udowodnieniem związku krwi retrahenta oraz pierwotnego sprzedawcy rzeczy ${ }^{59}$. Opiekun, będący często osobą niespokrewnioną z dzieckiem, mógł często nie wiedzieć o dokonanej sprzedaży. Jeżeli tymczasem zaniechał prawu małoletniego i uchybił terminowi, a pupil posiadał gotówkę wystarczająca do odzyskania nieruchomości, ponosił pełną odpowiedzialność $\mathrm{z}$ tego tytułu ${ }^{60}$.

W sytuacji, gdy do sprawowania opieki powołano dwóch lub więcej opiekunów (współopieka), ich odpowiedzialność miała charakter subsydiarny i solidarny. Nie była ona uzależniona od winy własnej danego tutora, lecz mogła być konsekwencją zawinionego działania lub zaniechania innego współopiekuna $^{61}$. W pierwszej kolejności odpowiadał ten $\mathrm{z}$ tutorów, który wyrządził realną szkodę. Jeżeli szkoda przewyższała wartość całego jego majątku, w zakresie różnicy odpowiadali dalsi tutorzy, choćby w rzeczywistości opieki nie wykonywali. Miało to zmotywować wszystkich powołanych opiekunów do rzetelnego wykonywania powierzonej im funkcji i kontroli sytuacji małoletniego, niezależnie od działań pozostałych osób.

${ }^{56}$ RL, s. 233 (art. $55 \S 7$ ).

${ }^{57} \mathrm{RN}$, s. $76-77$ (art. 79).

${ }^{58}$ RN, s. 111 (art. 21); zob. B. Lesiński, Ze studiów nad prawem bliższości w XIV i XV w., „Czasopismo Prawno-Historyczne” T. VII, 1955, z. 1, s. 92-108.

${ }^{59}$ Prawo bliższości oceniano w podobny sposób jak kolejność dziedziczenia beztestamentowego. RN, s. 112 (art. 28). Przypadki ustawowego wyłączenia rzeczy z retraktu określa art. $29 \mathrm{RN}$ (s. 113).

${ }^{60}$ RN, s. 112 (art. 26).

61 JC, s. 193-194 (cap. X). 
Oprócz zarządu nad dobrami opiekun zobowiązany był także troszczyć się o interesy osobiste dziecka. Rewizje podkreślają że tutora ustanawiano „nie tylko dla majątku, lecz także dla osoby [sieroty - P.K.]”62, co w praktyce oznaczało obowiązek utrzymania, wychowywania i jego wykształcenia, stosownie do stanu oraz możliwości finansowych wynikających z posiadanych przez niego dóbr. Oprócz materialnej strony opieki celem jej miało być ogólnie rozumiane przysposobienie do ,dobrych obyczajów” i tym samym ukształtowanie w małoletnim społecznie pożądanych zachowań, które dziecko powinno posiadać wchodząc w okres dorosłości. W razie nieposłuszeństwa opiekun zastępujący de facto naturalną władzę ojcowską był uprawniony do stosowania przysługujących rodzicowi środków poprawy. Według prawa nie poczytywano za czyn zabroniony bicia, szarpania za włosy, ćwiczenia rózgą i innych podobnych kar, jeśli karcenie dziecka miało jedynie cel wychowawczy, a skutek miał charakter powierzchowny, stosowny do rodzaju popełnionego występku ${ }^{63}$.

Prawo chełmińskie później aniżeli ustawodawstwo koronne przewidywało moment rozwiązania opieki ${ }^{64}$. W przypadku chłopców kończyła się ona wraz z osiagnięciem przez pupila pełnoletności, a więc $\mathrm{w}$ wieku 21 lat (w prawie polskim 18 lat) ${ }^{65}$. Musiał on być przy tym uznany za zdolnego do samodzielnego podołania swoim sprawom, w szczególności w odniesieniu do zarządu posiadanego majątku. Kobiety dla skuteczności ważniejszych czynności prawnych musiały mieć opiekuna niezależnie od wieku i stanu cywilnego. Naturalnymi opiekunami niewiasty był najpierw jej ojciec, a wraz z zamążpójściem mąż. Wiązały się z tym ograniczenia w zakresie zdolności procesowej oraz szerzej - zdolności do czynności prawnych. Rewizje prawa chełmińskiego stanowiły, że ,panny i niewiasty według prawa przed każdym sądem i w każdej sprawie powinny mieć przy sobie opiekuna, w przeciwnym razie sędzia nie powinien ich wysłuchać"'66. Jeżeli mąż znajdował się poza miejscem stałego zamieszkania i w związku z wyjazdem nie mógł reprezentować żony, niewiasta powinna wybrać w obecności sędziego innego tutora, najlepiej spośród bliskich krewnych. Ten rodzaj opieki miał charakter czasowy i gasł w momencie powrotu małżonka. Podobne obwarowanie dotyczyło kobiet niezamężnych. Teoretycznie i one były zobowiązane stawać przed sądem w asystencji najbliż-

${ }^{62}$ RN, s. 100 (art. 73 zd. 2).

${ }^{63}$ RL, s. 128 (art. 34), RN, s. 147 (art. 49).

${ }^{54}$ Por. J.W. Bandtkie, Prawo prywatne polskie napisane $i$ wyktadane przed rokiem 1830 w b. warszawskim aleksandryjskim uniwersytecie, Warszawa 1851, s. 193-197; T. Ostrowski, Prawo cywilne albo szczególne narodu polskiego z statutów i konstytucyi koronnych i litewskich zebrane rezolucyami Rady Nieustaiqcej obiaśnione $z$ dodatkami z praw kanonicznego, magdeburskiego, chetmińskiego pomnożone i porzqdkiem praw rzymskich, t. I, Warszawa 1784, s. 80-81; por. też P. Szczerbic, Speculum Saxonum, s. 289.

${ }_{66}^{6}$ JC, s. 191 (cap. V).

${ }^{66}$ RL, s. 234-235 (art. 57), RN, 101 (art. 76); JC, s. 194 (cap. XI). 
szego męskiego krewnego, jednakże, jak zauważa Groicki, często „,biorą sobie [niewiasty - P.K.] ku tej sprawie i ku innym wszelkim ważnym sprawom za opiekuna kogo chca, wedle myśli swojej, kto się jednokolwiek na ten czas trafi, okrom brakowania, nie mając żadnego baczenia na to, jeśli on człowiek wzięty za opiekuna, jest znajomy, jeśli obcy, jeśli krewny, przyrodzony, jeśli ku tej rzeczy sprawny, jeśli z gotową radą do sądu przyszedl, jedno kto się kolwiek na ten czas nawinie, tedy go sobie za opiekuna biora, a sąd go też wnet potwierdza"67. Skutkiem tego miał być pozorny udział tutora, który nie będąc wprowadzony w szczegóły nie potrafił skutecznie reprezentować kobiety, co $\mathrm{z}$ kolei znajdowało odzwierciedlenie w wyniku danej sprawy.

Jak tłumaczy przepis, ograniczenia zdolności procesowej kobiet wynikały z faktu, że miały one ,więcej łaski u sądu niż mężczyźni, albowiem gdy one wypowiadają w sądzie słowa, które w jakiś sposób wydają się szkodliwe lub z uszczerbkiem dla ich sprawy czy prawa, tak że później temu zaprzeczałyby, nie [mogą być] zbite [ich twierdzenia] niczyim świadectwem"68. Dochodziła do tego kwestia ograniczeń w sferze rozporządzania majątkiem. W myśl ustawodawstwa chełmińskiego wszystkimi dobrami (wspólnymi i osobistymi), niezależnie od ich rodzaju oraz sposobu nabycia (kupno, sprzedaż, darowizna itd.) zarządzał konsekwentnie mąż. Bez jego wyraźnej zgody kobieta nie mogła dokonać praktycznie żadnej skutecznej w świetle prawa dyspozycji majątkowej. W przypadku kobiet niezamężnych prawo co prawda zezwalało na alienacje bez konieczności uzyskania akceptacji opiekuna, ale dawało jednocześnie moźliwość sprzeciwienia się takiemu rozporządzeniu przez ich spadkobierców ${ }^{69}$.

Powodami rozwiązania opieki były także śmierć opiekuna lub pupila oraz wspomniane odwołanie tutora. Jeżeli sprawujący pieczę zmarł przed jej zakończeniem, prawo wymagało, aby w to miejsce ustanowić nową. $Z$ kolei wzięcie go do niewoli, inaczej niż w prawie magdeburskim, nie pozbawiało go praw do prowadzenia spraw dziecka, a jedynie powodowało konieczność powołania opieki zastępczej na czas jego absencji ${ }^{70}$. Po uwolnieniu opieka była przywracana (tutela zastępcza wygasała), a opiekun odzyskiwał wszelkie wynikające $\mathrm{z}$ pełnionej funkcji prawa i obowiązki ${ }^{71}$. Tutor zastępczy odpowiadał $\mathrm{w}$ takim wypadku jedynie za działania lub zaniechania przypadające w czasie wykonywanego przez niego stosunku opiekuńczego. Bezwzględna za to przesłanką rozwiązania była śmierć podopiecznego.

Po rozwiązaniu opieki opiekun zobowiązany był do zwrócenia pupilowi wszystkich składników majątku i pełnego rozliczenia się ze sprawowanego

${ }^{67}$ B. Groicki, Tvtutv, s. $179-180$

${ }^{68}$ RN, s. 101 (art. 76).

${ }^{69} \mathrm{RN}$, s. 86 (art. 22).

${ }^{70}$ P. Szczerbic, Speculum Saxonum, s. 298

71 RL, s. 233 (art. 55 § 3). 
nad nim zarządu ${ }^{72}$. Jeżeli nie wykryto nieprawidłowości, a dotychczasowy podopieczny nie skorzystał z prawa zaskarżenia jego działań, był on ostatecznie kwitowany oraz zwyczajowo zwalniany z dalszej odpowiedzialności. W przypadku zgonu tutora do wydania mienia zobligowany był każdy $\mathrm{z}$ aktualnych posiadaczy, będących $\mathrm{z}$ reguły spadkobiercami zmarłego ${ }^{73}$. Pupilowi przysługiwało w tym względzie odpowiednie roszczenie skuteczne erga omnes, które mógł zrealizować samodzielnie (jeżeli był pełnoletni) bądź przez nowego opiekuna. 
